Dr Radun Jeremić, pukovnik, dipl. inž. Vojna akademija - Odsek logistike, Beograd

\section{PRIVREDNI EKSPLOZIVI I NEKI ASPEKTI NJIHOVE PRAKTIČNE PRIMENE}

\author{
UDC: 662.24
}

Rezime:

Privredni eksplozivi primenjuju se za miniranja u rudnicima, kamenolomima, pri izgradnji puteva, pruga, rušenju zgrada, kao i u specijalne svrhe, kao što su zavarivanje metala, seizmička istraživanja, itd. $U$ radu je prikazan razvoj privrednih eksploziva, kao $i$ osobine i namena najvažnijih sastava koji se danas najviše primenjuju u praksi. Prikazana je metoda optimizacije miniranja „Power-deck“, koja se primenjuje radi uštede količine eksploziva, poboljšanja fragmentacije i smanjenja potresa zemljišta.

Ključne reči: privredni eksplozivi, sredstva za rušenje, miniranje stena.

\title{
COMERCIAL EXPLOSIVES AND SOME ASPECTS OF THERE PRACTICAL USE
}

Summary:

Commercial explosives are used for mining in main, quarries, construction of road and railway-track, building demolition and for special purpose as metal welding, seismic investigation etc. In this paper a shot historical overview of commercial explosives development is given and presented properties and use of some compositions that have the greatest practical importance in our country and in the world. The „Power-deck" method for quarrying optimization, using for explosive consumption decreasing, also is presented.

Key words: commercial explosives, blasting agents, quarrying.

\section{Uvod}

Za razliku od vojnih eksploziva, koji su, uglavnom, bazirani na čistim jedinjenjima, privredni (komercijalni) eksplozivi sastoje se od oksidansa, reducensa, senzibilizatora i inertnih komponenti, zbog čega imaju heterogenu strukturu. S obzirom na njihovu primenu sastav im se podešava tako da se postigne uravnoteženi ili blago pozitivni bilans kiseonika, kako u produktima eksplozije ne bi nastale značajnije količine otrovnih gasova (nitrozni gasovi i ugljenmonoksid).
Sa aspekta osetljivosti prema američkim DoT standardima (US Department of Transportation) danas se privredni eksplozivi dele na dve grupe: pravi eksplozivi i sredstva za rušenje. Osnovna razlika između njih je u osetljivosti, odnosno načinu inicijacije. Eksplozivi su osetljivi na detonatorsku kapislu br. 8, dok se sredstva za rušenje mogu inicirati samo pomoću pojačnika (bustera). Kojoj grupi će neki privredni eksploziv pripadati zavisi isključivo od njegovog sastava. Ako u sebi ne sadrži ni jednu komponentu koja se klasifikuje kao čist eksploziv onda spada u 
sredstva za rušenje, a u suprotnom se klasifikuje kao pravi eksploziv.

Zbog male osetljivosti na inicijaciju sredstva za rušenje su izuzetno bezbedna za transport, skladištenje i manipulaciju, usled čega ne podležu strogim propisima koji važe za prave eksplozive. To umnogome pojednostavljuje a samim tim i pojeftinjuje njihovu proizvodnju i primenu.

Zbog heterogene strukture, a i relativno male gustine, pri detonaciji privrednih eksploziva dolazi do većih gubitaka $u$ hemijskoj energiji u odnosu na vojne eksplozive, postižu se manje brzine detonacije i mnogo više je izražen rušeći efekat u odnosu na brizantni eksploziv.

Savremeni privredni eksplozivi poseduju mnogo veću stabilnost i otpornost na vlagu u odnosu na tradicionalne, a prilagođeni su i za mehanizovano direktno punjenje bušotina (pumpanjem).

\section{Razvoj privrednih eksploziva}

Energija eksplozije prvi put je primenjena za miniranje početkom 17 . veka. Godine 1627. Caspar Weindl iz Slovačke [1] zvanično je prvi put primenio crni barut za podzemno miniranje.

Sve do polovine 19. veka crni barut je ostao jedino sredstvo za miniranje. Revolucija u razvoju i primeni eksplozivnih materija, kako za vojne, tako i za civilne potrebe nastupa 1865 . godine, kada je Šveđanin Alfred Nobel pronašao dinamit. Izuzetno osetljiv i snažan tečni eksploziv nitroglicerin, koji je 20 godina ranije sintetizovao Ascanio Sobrero, Nobel je pomešao sa dijatomejskom zemljom (kiselgur, prirodni hidratisani silikat velike specifične površine), čime ga je učinio bezbednim za manipulaciju i tako proizveo dinamit. Novi eksploziv naglo je osvojio svet, jer je omogućio brzo i ekonomično vađenje rude i uglja, probijanje tunela i izgradnju puteva i železničkih pruga. Za inicijaciju dinamita Nobel je koristio detonatorsku kapislu sa živinim fulminatom. Pronalazak i proizvodnja dinamita doneli su Nobelu ogroman profit koji je i danas osnova dodeljivanja Nobelove nagrade za najznačajnija dostignuća u različitim naučnim oblastima.

I danas su eksplozivi, koji kao senzibilizator koriste nitroglicerin, poznati kao dinamiti. Oni predstavljaju prvu generaciju privrednih eksploziva. Njihova proizvodnja i primena sve više se izbegava zbog mnogih akcidenata, koji su posledica velike osetljivosti nitroglicerina.

Već 1867. godine u Švedskoj je patentiran i u praksi primenjen eksploziv za rušenje na bazi amonijumnitrata (bez nitroglicerina), koji je kasnije bio osnova, kako za proizvodnju privrednih eksploziva sa ili bez eksplozivnih komponenti, tako i za izradu različitih eksplozivnih smeša za vojne potrebe, najčešće sa trinitrotoluenom (amatoli).

Sastavi u kojima se kao senzibilizator primenjuje neki od brizantnih eksploziva (TNT, metilamin nitrat i drugi) pripadaju drugoj generaciji privrednih eksploziva. Oni su mnogo bezbedniji od dinamita, ali zbog prisustva eksplozivne komponente nisu potpuno bezbedni za proizvodnju i primenu.

Treću generaciju privrednih eksploziva čine potpuno bezbedni sastavi koji ne sadrže ni jednu komponentu koja se klasifikuje kao čist eksploziv (ANFO, slari i emulzioni eksplozivi). 
Prvi eksplozivi ANFO (Ammonium Nitrate Fuel Oil) našli su širu primenu u praksi tek nakon 1950. godine. Oni se sastoje od amonijumnitrata, kao oksidansa, i neke gorive komponente (mineralno ulje, dizel gorivo). Ovi, pre svega jeftini eksplozivi, imaju najširu primenu u svetu, naročito zbog jednostavne proizvodnje i bezbedne manipulacije. Međutim, njihov glavni nedostatak je velika osetljivost na vlagu, što je posledica higroskopnosti amonijumnitrata. Zato se ovi eksplozivi primenjuju samo u suvim uslovima.

Amerikanac Melvin A. Cook je 1956. godine uspeo prvi da izradi vodootporne eksplozive ANFO. Eksplozivnu smešu sastavljenu od amonijumnitrata, vode i aluminijuma u prahu uspešno je primenio u praksi za rušenje u vlažnim uslovima. Ova smeša imala je izgled paste, blatnjave kozistencije, zbog čega je nazvana „slurry eksploziv“".

U SAD je 1970. godine uspešno razvijena najnovija generacija jednostavnih vodootpornih eksploziva na bazi neorganskih soli - nitrata, tzv. emulzionih eksploziva, koji ne sadrže eksplozivne komponente.

\section{Savremeni privredni eksplozivi}

Danas se u svetu i kod nas proizvodi veliki broj različitih tipova i sastava privrednih eksploziva, namenjenih za različita miniranja. Sastavi koji sadrže bar jednu komponentu koja se klasifikuje kao čist eksploziv tretiraju se kao pravi eksplozivi, a sastavi koji ne sadrže nijednu eksplozivnu komponentu tretiraju se kao sredstva za rušenje.

Pravi eksplozivi osetljivi su na detonatorsku kapislu br. 8, dok je za inicijaci- ju sredstava za rušenje potreban pojačnik. Uopšte, sastavi koji se tretiraju kao pravi eksplozivi imaju bolje eksplozivne karakteristike, ali su skuplji, manje bezbedni, pa zahtevaju primenu mnogo strožih mera pri proizvodnji, transportu, skladištenju, manipulaciji i primeni u odnosu na sredstva za rušenje.

Tendencije u razvoju privrednih eksploziva usmerene su na povećanje energije, smanjenje cene, povećanje vodootpornosti, fizičke i hemijske stabilnosti, kao i manjoj primeni eksplozivnih komponenti radi povećanja bezbednosti.

\section{Eksplozivi na bazi nitroglicerina}

Prvi privredni eksploziv - dinamit, izrađen je na bazi nitroglicerina. Nitroglicerin apsorbovan na dijatomejskoj zemlji bio je bezbedan za transport i upotrebu. Većina savremenih dinamita sadrži nitroglicerin kao senzibilizator i ujedno izvor energije. Od svih privrednih eksploziva oni imaju najveću energiju i brzinu detonacije (preko $6000 \mathrm{~m} / \mathrm{s}$ ), a otporni su i na vlagu. Međutim, njihov najveći nedostatak je visoka cena u odnosu na ostale eksplozive i relativno veliki rizik u proizvodnji, zbog čega se danas sve manje proizvode i primenjuju. Pošto u svom sastavu sadrže nitroglicerin tretiraju se kao pravi eksplozivi. Laborišu se u cilindrična punjenja (papir ili plastiku) prečnika $20 \mathrm{~mm}$ ili većih, različitih dužina.

Postoje tri osnovna tipa dinamita: praškasti, semiželatinozni i želatinozni. Semiželatinozni i želatinozni dinamiti sadrže nitrocelulozu koja u kombinaciji sa nitroglicerinom formira gel $\mathrm{u}$ relativno velikom procentu. Ovu vrstu dinamita Nobel je nazvao razorni želatin. 
Nakon Drugog svetskog rata naglo je opala primena razornog želatina zbog visoke cene, osetljivosti na udar i trenje, kao i lake zapaljivosti.

Vremenom sve veći procenat nitroglicerina u dinamitima zamenjuje amonijumnitrat, čime oni postaju znatno jeftiniji i bezbedniji za proizvodnju i upotrebu. U švedskom razornom želatinu, koji je originalno sadržavao $92 \%$ nitroglicerina i $8 \%$ nitroceluloze, postepeno je sadržaj nitroglicerina smanjivan sve do $20 \%$, tako da se sveo na ulogu senzibilizatora [2].

\section{Eksplozivi na bazi \\ amonijumnitrata i TNT-a}

Zbog niže cene i vrlo male osetljivosti, TNT je mnogo pogodniji za izradu eksplozivnih smeša sa amonijumnitratom u odnosu na nitroglicerin, bez obzira na to što ovi sastavi imaju manju energiju $u$ odnosu na dinamite.

Smeša koja se sastoji od 79\% amonijumnitrata i $21 \%$ TNT-a ima nulti bilans kiseonika, a pri eksploziji oslobađa oko $85 \%$ energije u odnosu na razorni želatin. Međutim, ovaj sastav je zbog velikog udela TNT-a dosta skup i nije isplativ za komercijalnu primenu. U praksi se koriste sastavi u kojima udeo TNT-a varira od 5 do $15 \%$, zavisno od namene eksploziva.

Pored navedenih komponenti ovi eksplozivi mogu sadržavati i aluminijum u prahu koji se dodaje za povećanje energije, zatim dinitrotoluen, drveno brašno, nitrocelulozu, karboksimetilcelulozu, itd.

Kao i dinamiti, sastavi na bazi amonijumnitrata i TNT-a tretiraju se kao pravi eksplozivi. Oni su zbog amonijumni- trata osetljivi na vlagu, tako da se primenjuju samo u suvim uslovima. Bilo je puno pokušaja da se naprave sastavi koji su otporni na vlagu. U tu svrhu u uslovima toplog mešanja dodaju se male količine voska, ali se time smanjuje njihova osetljivost. Bolji rezultati postignuti su dodavanjem kalcijumovih sapuna, kao što je kalcijumstearat.

Po svojoj konzistenciji ovi eksplozivi se, uglavnom, proizvode u praškastom obliku i pakuju u odgovarajuće patrone izrađene od parafinskog papira ili plastike. Zavisno od sastava i prečnika punjenja brzina detonacije im se kreće od 3000 do $5000 \mathrm{~m} / \mathrm{s}$. Primenjuju se za miniranje srednje tvrdih i tvrdih stena.

\section{Eksplozivi ANFO}

Privredni (komercijalni) eksplozivi ANFO (Ammonium Nitrate Fuel Oil) danas se, zbog niske cene i jednostavne proizvodnje, najviše primenjuju u praksi (oko 80\%), pre svega za površinsko miniranje mekih i srednjetvrdih stena. Spadaju u grupu vrlo neosetljivih (teško detonabilnih) eksploziva, jer ne sadrže nijednu komponentu koja se klasifikuje kao čist eksploziv. Ne mogu se inicirati detonatorskom kapislom, već isključivo pojačnikom detonacije - busterom, pa se klasifikuju u sredstva za rušenje.

Pogodni su i bezbedni za manipulaciju, transport i skladištenje, a i vrlo su ekonomični.

U osnovi, eksplozivi ANFO predstavljaju smešu od 94\% (mas) amonijumnitrata u obliku poroznih granula (prilovani amonijumnitrat) male gustine, koji ima ulogu oksidansa, i 6\% dizel goriva. 
Stehiometrijski odnos je 94,5:5,5, ali se primenjuje odnos 94:6 da bi se obezbedila potpuna hemijska reakcija amonijumnitrata:

$$
3 \mathrm{NH}_{4} \mathrm{NO}_{3}+\mathrm{CH}_{2} \longrightarrow 7 \mathrm{H}_{2} \mathrm{O}+\mathrm{CO}_{2}+3 \mathrm{~N}_{2}
$$

Produkti eksplozivnog razlaganja su netoksični, mada se u vrlo malim količinama javljaju i $\mathrm{CO}$ i $\mathrm{NO}_{2}$.

Granule amonijumnitrata moraju zadovoljavati specifične zahteve u pogledu sposobnosti apsorpcije i zadržavanja dizel goriva, sadržaja vlage, veličine čestica, gustine i posebno termičke stabilnosti. Optimalna je sledeća distribucija veličina granula [3]: $>2 \mathrm{~mm}-15 \% ; 1-2$ $\mathrm{mm}-80 \% ; 0,5-1 \mathrm{~mm}-5 \%$.

Sam amonijumnitrat, ako u svom sastavu ima manje od $0,2 \%$ sagorljivih materija, prema UN klasifikaciji spada u grupu 5.1. (oksidans), zbog čega nema posebnih ograničenja u pogledu manipulacije, transporta i skladištenja. Može se skladištiti u velikim količinama blizu mesta miniranja, gde se može mešati sa dizel gorivom i odmah primenjivati za miniranje. Međutim, treba naglasiti da i ovakav amonijumnitrat može detonirati ako se inicira dovoljno snažnim početnim impulsom.

Eksplozivi ANFO mogu sadržavati i druge neeksplozivne komponente, kao što su: aluminijum u prahu, ferosilikon, ugljena prašina, karboksimetilceluloza, itd. Dodavanje eksplozivne komponente, kao što je TNT, menja klasifikaciju od sredstva za rušenje u pravi eksploziv. Sastavi koji sadrže 5\% TNT-a mogu se inicirati detonatorskom kapislom br. 8 .

Za postizanje maksimalne energije eksploziva ANFO najvažnije je što bolje mešanje komponenti. To se najbolje postiže u namenskim specijalnim vozilima - mikserima, koja poseduju svu elektronsku i hidrauličku opremu za proizvodnju i pneumatsko punjenje minskih bušotina.

Mnogo jednostavniji način, koji daje dobre rezultate, jeste direktno nalivanje granula amonijumnitrata u otvorenim vrećama sa 8 do10\% dizel goriva. Pola sata nakon nalivanja goriva vrši se odlivanje viška goriva. Pri tome, amonijumnitrat zadrži približno potrebnu količinu goriva (oko 6\%). Najjednostavniji način je da se sukcesivno pune bušotine sa po jednom do dve vreće amonijumnitrata, nakon koje se naliva potrebna količina dizel goriva i postupak se ponavlja do pune bušotine (gorivo disperguje relativno lako i brzo).

Pri iniciranju je važno da se obezbedi dovoljno jak početni impuls, kako bi se obezbedilo pouzdano aktiviranje punjenja u bušotini. U suprotnom, može doći do pojave male brzine detonacije ili do gašenja detonacije. Radi toga se busteri mogu rasporediti i duž bušotine. Zato buster treba da bude istog prečnika kao i punjenje i da je dovoljno dugačak da bi se obezbedila stabilna detonacija. Pored toga, treba da ima veću brzinu detonacije od osnovnog punjenja (slika 1).

Brzina detonacije ANFO eksploziva izrazito zavisi od prečnika bušotine, a i od gustine punjenja. U optimalnim uslovima brzina detonacije može dostići i $4800 \mathrm{~m} / \mathrm{s}$ (pri maksimalnoj gustini od $1,1 \mathrm{~g} / \mathrm{cm}^{3}$ ). $\mathrm{Ne}$ preporučuje se da prečnik punjenja (bušotine) bude manji od $70 \mathrm{~mm}$. Ispod $\mathrm{d}=25 \mathrm{~mm}$ dolazi do gašenja detonacije bez obzira na snagu početnog impulsa. 


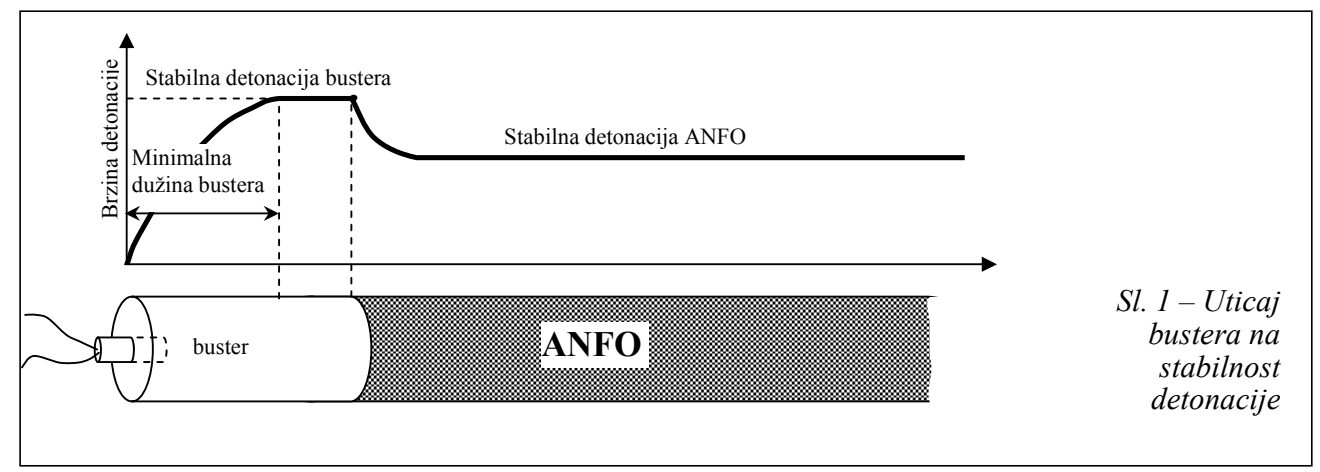

Gravimetrijska gustina eksploziva varira od $0,75 \mathrm{do} 0,95 \mathrm{~g} / \mathrm{cm}^{3}$, što zavisi od veličine i gustine čestica amonijumnitrata, a maksimalna gustina koja se praktično može postići iznosi $1,1 \mathrm{~g} / \mathrm{cm}^{3}$.

Pošto je propisno balansiran kiseonikom, s obzirom na neškodljive produkte eksplozije, eksplozivi ANFO mogu se koristiti i za podzemna miniranja.

Nekada se ovaj eksploziv primenjivao upakovan, jer je tako bio zaštićen od vode, međutim, mana mu je otežano punjenje bušotina i pojava zazora između punjenja i zida bušotine, što se odražava na iskorišćenost energije.

Prednost slobodnog nasipanja i punjenja bušotina jeste što je taj postupak znatno ekonomičniji i što se na taj način popunjava cela bušotina, čime se postiže efikasnije iskorišćenje energije eksplozije.

Pošto je amonijumnitrat rastvorljiv u vodi, u slučaju vlažnih bušotina iz njih se najpre mora odstraniti voda. Pojava narandžastosmeđih gasova nakon eksplozije ukazuje na prisustvo vode u bušotinama. Mogu se koristiti i plastične patrone prečnika bušotine koje se stavljaju u bušotinu, a zatim se pune eksplozivom. Pri tome, mora se voditi računa o statičkom elektricitetu, naročito ako se punjenje vrši pneumatskim putem.

$\mathrm{U}$ poslednje vreme razvijeni su i eksplozivi ANFO za miniranje u vlažnim uslovima. Ovi sastavi sadrže posebne komponente koje u kontaktu sa vodom formiraju gel koji sprečava dalje prodiranje vode i rastvaranje amonijumnitrata [4] ili oslobađaju gasove koji potiskuju vodu sa dna bušotine i u gelu koji se postepeno stvara formiraju mehuriće koji omogućuju lakše prihvatanje detonacije [5].

\section{Vodoplastični eksplozivi}

Vodoplastični, kašasti ili slari (Slurry) eksplozivi (tzv. vodeni gel) jesu privredni eksplozivi za masovnu upotrebu razvijeni u SAD šezdesetih godina prošlog veka. To su vodootporni eksplozivi namenjeni za rušenja u vlažnim uslovima. Predstavljaju smešu vodenog rastvora oksidansa, najčešće amonijumnitrata, natrijumnitrata i kalcijumnitrata (koriste se i kalijumnitrat, kalijumperhlorat, amo- 
nijumhlorat i metilaminnitrat) i nerastvorne tečne i/ili čvrste gorive komponente koja reaguje sa oksidansom (aluminijum, ugljena prašina, šećer, brašno, glikol, nafta). Sadržaj vode, u kojoj je potpuno ili većim delom rastvoren amonijumnitrat, kreće se od 10 do 20\%. Dodavanjem posebne komponente (guar guma ili neko sredstvo za umrežavanje) vrši se njihovo zgušnjavanje, čime se prevode u želatinozno stanje [6]. Ako im se doda komponenta koja se klasifikuje kao čist eksploziv, menjaju klasifikaciju od sredstva za rušenje u prave eksplozive.

Slari-sredstvima za rušenje mogu se dodavati i senzibilizatori kao što su delaborisani baruti i eksplozivi, ugljena prašina, sumpor, aluminijum, itd. U novije vreme senzibilizacija slari-eksploziva sve više se vrši ubacivanjem velikog broja staklenih mikrobalona sa vazduhom, prečnika do $0,1 \mathrm{~mm}$, koji igraju ulogu „vrućih tačaka“, što je jeftinije i mnogo bezbednije. Brzina detonacije im se može podešavati prema karakteru tla za miniranje a najviše zavisi od sastava i prečnika punjenja i kreće se u širokim granicama od 1500 do $5500 \mathrm{~m} / \mathrm{s}$.

Kod slari-eksploziva prečnik punjenja manje utiče na brzinu detonacije $u$ odnosu na eksplozive ANFO. Gustina ovih eksploziva kreće se od 1,0 do 1,6 $\mathrm{g} / \mathrm{cm}^{3}$. Direktno punjenje bušotina pri miniranju ima prednosti u odnosu na punjenje patronama, isto kao i kod eksploziva ANFO. Za miniranje jako tvrdih stena dodaje se aluminijum koji izrazito povećava energiju eksplozije.

\section{Emulzivni eksplozivi}

Pojam emulzivni eksploziv načelno se koristi za smeše visokokoncentrovanih rastvora neorganskih soli - oksidansa i gorivih komponenti. Sastav se stabilizuje u obliku emulzije ,voda u gorivu“ pomoću odgovarajućih sredstava za emulgovanje. Sastoje se od kontinuelne i diskontinuelne faze.

Diskontinuelnu fazu čini vodeni rastvor oksidansa (amonijumnitrata, natrijumnitrata ili kalcijumnitrata) koji je u obliku finih kapi raspoređen u kontinuelnoj fazi koju čini goriva komponenta (dizel gorivo, vosak, mineralno ili biljno ulje). Pored toga, može se dodavati i aluminijum u prahu za povećanje energije. Diskontinuelnu fazu čini 80 do 95\% emulzije.

Klasifikuju se kao sredstva za rušenje, jer u svom sastavu ne sadrže nijednu eksplozivnu komponentu. To su danas najbezbedniji eksplozivi sa aspekta proizvodnje, transporta, skladištenja i manipulacije. Otporni su na vodu i pri detonaciji ne oslobađaju otrovne produkte. Da bi se mogli inicirati dodaju im se stakleni mikrobaloni ili reagensi za oslobađanje mehurića vazduha (nitriti u kombinaciji sa tioureom), koji služe kao vruće tačke. Ujedno, stakleni mikrobaloni, kao i prilovani amonijumnitrat, najčešće se koriste za podešavanje gustine emulzivnih eksploziva. U proizvodnji ovih eksploziva najvažnija faza je emulgovanje od koje zavisi brzina detonacije i stabilnost. Kapi diskontinualne faze su pri odnosu od oko 10:1 deformisane i emulzija nije uniformna, tj veličina kapi se kreće u određenom rasponu. Zbog velikih površinskih sila u ovim uslovima u emulziju se dodaju površinski aktivne materije emulgatori. Svojim liofilnim delom one se rastvaraju u gorivu, a liofobnim delom u vodenom rastvoru soli. Tako raspore- 
đene na granici faza ove materije smanjuju površinski napon i stabilišu saćastu strukturu emulzije.

Kao emulgatori najčešće se koriste estri masnih kiselina i sorbitana (anhidrid sorbitola, šestohidroksilnog alkohola), zatim kalcijumstearat, estri fosforne kiseline, mono i digliceridi masnih kiselina, itd. Emulgator se dodaje u količini 1 do 5\%.

$\mathrm{Na}$ emulgovanje utiče sastav diskontinualne i kontinualne faze, odnos diskontinualne i kontinualne faze, tip emulgatora, vreme i brzina mešanja. Ovi parametri direktno utiču na karakteristike emulzivnih slari-eksploziva. Eksperimetalno je dokazano da je optimalna veličina kapi oko jednog mikrona, a postiže se pri brzini mešanja većoj od $1000 \mathrm{o} / \mathrm{min}$ [7].

Brzina detonacije ovih eksploziva kreće se oko $5000 \mathrm{~m} / \mathrm{s}$, što zavisi od sastava, gustine i prečnika punjenja.

Emulzivni eksploziv, koji se sastoji od oko $60 \%$ amonijunitrata, $15 \%$ natrijumnitrata, $15 \%$ vode, $6 \%$ dizel goriva, $2 \%$ emulgatora i $2 \%$ staklenih mikrobalona, ima odličnu stabilnost i brzinu detonacije od oko $4600 \mathrm{~m} / \mathrm{s}\left(\rho=1,2 \mathrm{~g} / \mathrm{cm}^{3}\right)$ [7].

U poslednje vreme emulzivni eksplozivi se sve češće kombinuju sa eksplozivima ANFO. Taj odnos se kreće od 20/80 u manje vlažnim uslovima, do 80/20 u izrazito vlažnim uslovima miniranja.

Emulzivni eksplozivi mogu se pakovati u patrone ili proizvoditi na licu mesta u specijalnim vozilima i direktno nalivati u bušotine.

\section{Eksplozivi za podzemno miniranje}

Pri podzemnom miniranju, posebno u rudnicima uglja, postoji rizik od eks- plozije smeše metana ili ugljene prašine i vazduha. U takvim slučajevima zabranjena je upotreba konvencionalnih eksploziva, koji se zbog toga označavaju kao nemetanski eksplozivi. Međutim, eksplozije gasnih smeša ne započinju odmah sa pojavom prve varnice. Zavisno od temperature plamena do inicijacije dolazi sa zadrškom i do nekoliko sekundi. Pri temperaturi plamena od $650^{\circ} \mathrm{C}$ to vreme iznosi oko $10 \mathrm{~s}$, dok pri temperaturi od $1100^{\circ} \mathrm{C}$ pada na $1 \mathrm{~s}$. Da bi se izbegla mogućnost pojave eksplozije, u takvim uslovima moraju se koristiti eksplozivi sa sniženom temperaturom eksplozije, poznati kao metanski eksplozivi. Zato se privrednim eksplozivima dodaje i do $40 \%$ natrijumhlorida koji ima relativno veliku toplotnu vodljivost i specifičnu toplotu, usled čega apsorbuje toplotu od vrelih gasovitih produkata i time znatno snižava temperaturu eksplozije.

Visokobezbedni eksplozivi su sastavi koji sadrže inverzne soli u paru. Umesto potencijalno eksplozivnog amonijumnitrata inertni amonijumhlorid i natrijumnitrat se dodaju u sastav. Pri detonaciji eksplozivne komponente iz sastava u bušotini, na primer nitroglicerina, oslobođena energija biće koncentrisana u samoj bušotini. Ova energija biće dovoljna za kratkotrajno stvaranje amonijumnitrata i natrijumhlorida koji će odmah reagovati na već opisan način. Ako se eksplozija odigrava van bušotine, u kontaktu sa eksplozivnom smešom metana i vazduha detonacija eksplozivne komponente uzrokovaće odbacivanje obe komponente iverznih soli, čime ce eksplozija metana biti izbegnuta. 


\section{Optimizacija postupka miniranja}

Pri realizaciji različitih miniranja jedan od važnih zahteva je ekonomičnost. S obzirom na to da se pri miniranju (posebno u kamenolomima) troše ogromne količine eksploziva, postoji težnja da se pri tome troši što manje eksploziva i da, po mogućstvu, on bude što jeftiniji. U poslednje vreme radilo se na usavršavanju različitih tehnika miniranja čiji je cilj bio ušteda na eksplozivu, smanjenje vibracija i potresa zemljišta, poboljšanje fragmentacije i eliminacija bušenja ispod određenog nivoa.

Jedna od novih tehnika, nazvana „Power Deck“ [8], zasniva se na posebno organizovanom punjenju bušotina koje se sastoji od specijalno dizajniranog čepa, vazdušnog prostora na dnu bušotine i unapred definisane mase za zaptivanje vrha bušotine sa istovremenim iniciranjem sa gornje i donje strane punjenja. Efikasnost nove metode praktično je dokazana realizacijom određenih eksperimenata pri miniranju stena (slike 2, 3 i 4).

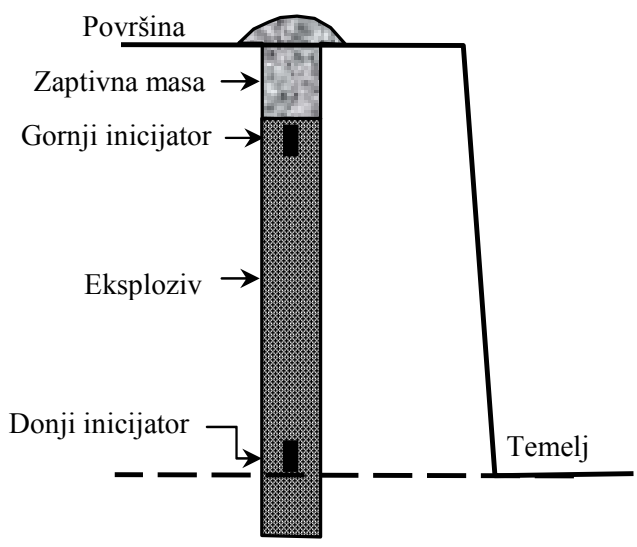

Sl. 2 - Standardno napunjena bušotina koja se prostire ispod nivoa temelja
$\mathrm{Na}$ slici 2 prikazana je standardno pripremljena bušotina za miniranje, koja zahteva određeno bušenje i ispod nivoa temelja tla. Vrh bušotine zaptiva se sitnijom granulacijom miniranih stena, a aktiviranje eksplozivnog punjenja vrši se istovremeno sa donje i gornje strane.

Na slici 3 prikazana je suština metode „Power Deck“, čija je osnova specijalni čep od plastike sa drvenim distancerima, pomoću kojeg se na dnu bušotine ostavlja vazdušni stub određene visine. Iniciranje eksploziva vrši se električnim putem, istovremeno odozgo i odozdo, uz pomoć bustera.

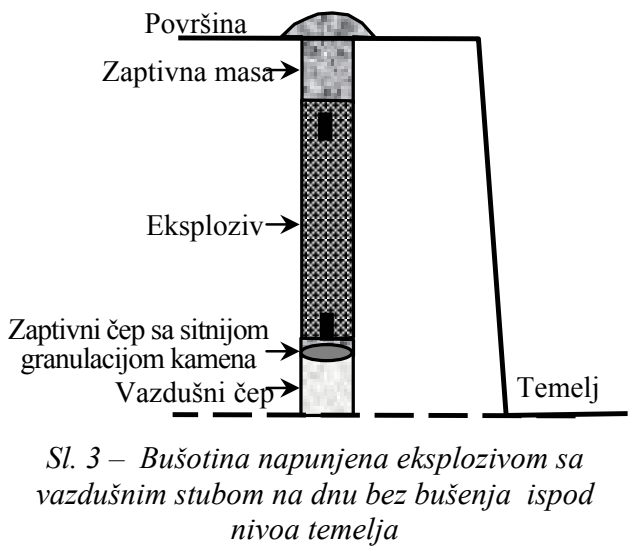

Sa ovako realizovanim punjenjem, $u$ odnosu na prethodni slučaj, ostvarene su uštede u eksplozivu od $17 \%$, za oko $30 \%$ su smanjene vibracije zemljišta, fragmentacija je poboljšana za $25 \%$, a eliminiše se i potreba za bušenjem ispod nivoa temelja.

Ako se miniranje realizuje sa dva eksplozivna punjenja, odvojena vazdušnim segmentom u sredini i vazdušnim segmentom na dnu bušotine (slika 4), ostvaruje se ušteda u eksplozivu za oko $25 \%$ u odnosu na standardni način miniranja. 


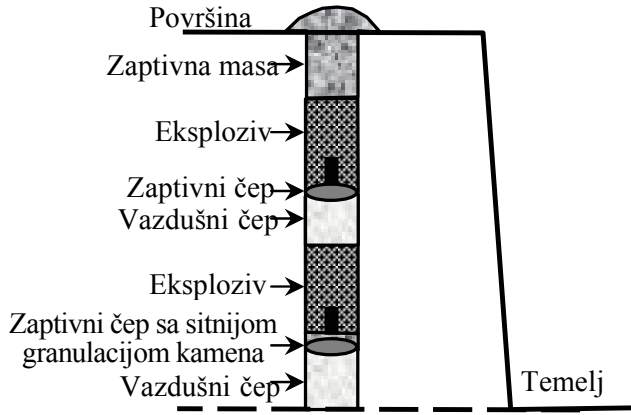

Sl. 4 - Bušotina sa dva eksplozivna punjenja odvojena vazdušnim segmentom u sredini $i$ vazdušnim segmentom na dnu

Pri miniranju stena u kamenolomima teži se da se postigne fragmentacija koja je najpribližnija željenoj, kako bi se izbegla naknadna operacija usitnjavanja, što umnogome poskupljuje konačni proizvod. Zbog velikog broja parametara koji utiču na proces fragmentacije stena, teško je postaviti pouzdan model koji će dati precizne rezultate. Jedan od najpoznatijih matematičkih modela koji se danas primenjuje u praksi za optimizaciju fragmentacije je tzv. model fragmentacije Kuz-Ram [9] koji se zasniva na kombinaciji karakteristika stena, karakteristika eksploziva i željenih parametara fragmentacije.

\section{Zaključak}

Danas se proizvodi veliki broj različitih tipova i sastava privrednih eksploziva namenjenih za različita miniranja. Zavisno od toga da li sadrže neku komponentu koja se klasifikuje kao čist eksplo- ziv ili ne, svrstavaju se u dve grupe: prave eksplozive i sredstva za rušenje. Pravi eksplozivi su osetljivi na detonatorsku kapislu br. 8 , dok je za inicijaciju sredstava za rušenje potreban pojačnik. U svetu i kod nas danas se, uglavnom, primenjuju sledeći tipovi privrednih eksploziva: sastavi na bazi nitroglicerina (dinamiti), sastavi na bazi amonijumnitrata $i$ TNT-a, eksplozivi ANFO, vodoplastični (slari) eksplozivi i emulzivni eksplozivi. Sastavi podešeni za podzemna miniranja, u uslovima kada postoji opasnost od eksplozije metana, tretiraju se kao metanski eksplozivi. Od svih sastava danas se najviše primenjuju eksplozivi ANFO, jer su najjeftiniji i izuzetno bezbedni za proizvodnju, manipulaciju i primenu.

Metodama optimizacije miniranja, kao što je metoda „Power Deck“, mogu se postići uštede u eksplozivu i poboljšanje fragmentacije i do $25 \%$.

\section{Literatura:}

[1] Ringgenberg, O.; Mathieua, J.: Commercial High Explosives, Chimia, 58, 2004, (390-393).

[2] Olofsson, O. S.: Applied Explosives Technology for Construction and Mining, APPLEX, Sweden, 1988.

[3] Prilled Ammonium Nitrate, VBC INDUSTRIES LTD www.vbcindia.com/industries.htm.

[4] Water resistant explosive composition, United States Patent 6261393, 2001.

[5] Solid sensitizers for water-in-oil emulsion explosives, United States Patent 4453989, 1984.

[6] Water-in-oil type emulsion explosive with chelating agent, United States Patent 4908080, 1990.

[7] Matejić-Grgurić, M.: Uticaj promene parametara diskontinualne faze emulzije na karakteristike emulzionog slari eksploziva, XXI simpozijum JKEM, Tara, 2001.

[8] Chiappetta, F.: New Blasting Technique to Eliminate Subgrade Drilling, Improve Fragmentation, Reduce Explosive Consumption and Lower Ground Vibrations, The Journal of Explosives Engineering, January/February, 2004.

[9] Kuz-Ram Fragmentation Model www.mininglife.com/Miner/blasting/Fragmentation.htm. 